Reviev Article

\title{
Some Recent Soviet Publications on Francisk Skaryna
}

\author{
BY
}

\author{
JAMES DINGLEY
}

\begin{abstract}
Recent years have seen a considerable increase in writing on Skaryna in the USSR. The time has now come for at least a preliminary examination of the results of this recent Soviet scholarship, and to attempt an evaluation of the role played by Byelorussian scholars in the emigration in producing this notable upsurge in publishing.
\end{abstract}

Let us first look at a bibliography: Je. L. Nemirovskij, Načalo knigopečatanija $v$ Belorussii $i$ Litve. Žizn' $i$ dejatel'nost' Franciska Skoriny. Opisanije izdanij i ukazatel' literatury, Moscow, 1978. The compiler in his introduction lays no claim to the exhaustiveness of his bibliography of works about Skaryna. Indeed he specifically excludes a whole area: 'However it was considered necessary to omit all reference to the mostly slanderous articles and notes that have appeared in the émigré press'. More detail on the nature of these omissions is given in the introductory article to the collection of papers that constituted the 'Fedorovskije čtenija 1977': Belorusskij prosvetitel' Francisk Skorina $i$ načalo knigopečatanija $v$ Belorussii $i$ Litve, Moscow, 1979 (subsequently referred to in this article as BPFS), p. 22. The author(s) of this anonymous article adopt(s) an expectedly hostile stance to the articles in Zapisy 5, Munich, 1970. It is therefore with the contents of this volume of Zapisy that Nemirovskij's bibliography should be compared. On p. 179 Dr V. Tumaš ('Scoriniana Nova 1926-1966') sets out eight requirements that need to be fulfilled for a true assessment of Skaryna. The second of these is especially relevant, and is therefore worth quoting in full: 'Układ i vydańnie kampletnaje biblijahrafii skarynijany - 'biblijahrafii ŭsiej isnujučaj pra Skarynu litaraturu, što raśkidanaja ŭ časie na praciahu blizu piaci stahodździaŭ'. The completeness of the bibliography is clearly a crucial issue; Nemirovskij's criteria for the omission of items require closer examination. His own statement quoted above, does not go into detail, but on p. 22 of BPFS we read: 'The relative importance of Soviet publications is artificially reduced in the bibliography [tha't of Dr Tumaš in Zapisy 5]. Serious Soviet scholarly works literally drown in a heap of references to articles and notes by all manner of anti-Soviet scribblers. These include, for example, 'works' published on the pages of Biełaruskaja hazieta, a newspaper that appeared in Minsk during the German occupation, or 
in Ranica, a newspaper that migrated to Berlin after the liberation of Byelorussia.' Soviet readers cannot check the accuracy of this remark; those fortunate enough to be able to use Tumaš' work will find one item (633) from Biełaruskaja hazieta and four items (640, 641, 643, 644) from Ranica. This is scarcely sufficient to drown the Soviet publications listed by both Tumaš and Nemirovskij.

Nemirovskij seems to attach the 'émigré' label to Byelorussian scholars living in Poland between the wars, to judge by their somewhat selective inclusion in his bibliography. A. Stankievič's Doktar Francišak Skaryna - pieršy drukar biełaruski, Vilna, 1925, is included, whereas his articles of 1936, published in the journal Kałośsie, are not. There are, not surprisingly, no references to works by Eastoŭski and A. Euckievič. It would be interesting to know what has happened to J. Gołąbek's Literatura białoruska (584 in Tumaš), which according to Nemirovskij's index should be listed as item 554 but which in fact has been omitted. What can have caused the exclusion of the 1933 Lietuviškoji enciklopedija (585 in Tumaš)?

Serious doubts about the value of Nemirovskij's bibliography arise as a result of the absence of any reference to Fr A. Nadson's work on the Malaja podorožnaja knižica and to the work of other Byelorussian scholars at present living in the West. If their work is intrinsically 'anti-Soviet', we would not expect to find references to them in Soviet publications, yet this is not the case. Florovskij refers to Braha's Doktar Skaryna $\breve{u}$ Maskvie, New York-Munich, 1963, in his 'Francisk Skorina i Moskva', TODRL XXIV, Leningrad, 1969, pp. 155-8. In his article 'Scoriniana' in 450 hod biełaruskaha knihadrukavańnia, Minsk, 1968, pp. 389-433, he refers to publications in Źnič, a Byelorussian Catholic journal from Rome. Fr Nadson's crucial article 'Kniha Skaryny ŭ Kapienhahienie', Božym šlacham, 5 (128), London, 1971, is first referred to by name in V. I. Luk'janenko, Katalog belorusskich izdanij Kirillovskogo šrifta XVI-XVII vv., Leningrad, 1973. The next mention of it is extremely interesting. It occurs in issue 7 (14) of Knygotyra, Vilna, 1979, which contains papers read at a conference on the earliest developments in printing in Lithuania and Byelorussia held in Vilna on 21 November 1975. Fr Nadson's article is cited in a paper by $A$. F. Koršunov, ' $K$ voprosu o načale knigopečatanija v Velikom knjažestve Litovskom', p. 28. (Ironically Koršunov is the author of the note 'Znojdziena "Paschalija", Pomniki historyi i kultury Bielarusi, 4, 1972 pp. 44-5, the first occasion on which Fr Nadson's discovery was brought to the attention of the Soviet reader, although neither he nor his article was named at the time.) Nemirovskij has a paper published in this collection. $\mathrm{He}$ is the deputy editor of BPFS, in which Fr Nadson's subsequent article 'Skaryna's Prayer Book', Journal of Byelorussian Studies, vol. 2, no. 4, London, 1972, pp. 339-58, is referred to twice; Fr Nadson's name also appears in the index. Nemirovskij cannot therefore claim ignorance of the achievements of Byelorussian 'émigré' scholarship, since many of his colleagues seem to be well aware of it.

By virtue of its obviously politically motivated omissions and disregard of scholarship, Nemirovskij's bibliography cannot be 
regarded as an updating of, let alone substitute for, that of Dr Tumaš.

While on the subject of Soviet attitudes to émigré Byelorussian scholarship, we should, in turning our attention to a more detailed consideration of $B P F S$, first look at the contribution by G. Ja. Golenčenko, 'Kritika buržuazno-nacionalističeskich postrojenij žizni i dejatel'nosti $F$. Skoriny'. With a title like that the perspicacious reader does not, of course, need the article itself. By failing to read it, however, he would deprive himself of the following masterly phrase: "Belorusskaja nacionalističeskaja "skoriniana" primitivna i kompiljativna po svoim vyvodam, uzka i fragmentarna po soderžaniju'. I must confess to being unable to understand what this means, unless we take 'kompiljativna' in respect of conclusions to be a hostile reference to the production of bibliographies, location lists of Skaryna's printed works and of documents related to him, and the like, in which case Golenčenko appears not to understand the need for painstaking compilation of source material as a sine qua non of historical research. 'Fragmentary content' could perhaps be understood as a sideswipe at the appearance of numerous short articles by Byelorussian émigré scholars on individual aspects of Skaryna's life and work, at their failure to produce a comprehensive monograph on him. Indeed they have not produced such a work, but neither have Soviet scholars, despite all the academic and financial backing that must surely be available to them. In any case, in Golenčenko's own terms is there not a danger that an all-embracing comprehensive work on Skaryna would be regarded as 'kompiljativna'?

Golenčenko is also the author of a much more useful contribution, 'Knigi Skoriny v belorusskich, russkich i ukrainskich sobranijach XVI-XVII vv.'. There are other important bibliographical contributions by Nemirovskij, (a compilation of Skaryna's editions, with location), I. V. Pozdejeva (on the Skaryna holdings of Moscow University Library) and B. V. Sapunov (on Byelorussian early printed books in Russian libraries in the seventeenth century). There are linguistic articles by Bulyko, 'Zapadno-slavjanskaja leksika v izdanijach Franciska Skoriny' and Žuravskij, 'Jazyk predislovij Franciska Skoriny'. The language of Skaryna's translations of Biblical texts is an important issue in V. M. Konon's article on his aesthetic views, especially in as much as it raises the problem of the language from which Skaryna was translating. Much of Konon's case seems to rest on Skaryna's identity of 'the good' and 'the beautiful', as reflected in his translations of those passages in which the Greek $\kappa \alpha \lambda$ ós occurs. (Lovers of the spectacularly odd should refer to p. 79 to see how this simple five-letter word is typographically mangled - twice!) $\mathrm{He}$ contrasts a number of passages in Old Church Slavonic, modern Russian and in Skaryna's translation. The point he makes is laboured and ultimately in vain. We may be reasonably certain that Skaryna did not translate direct from the Septuagint; he may therefore have been influenced more by the language of his source than by a conscious aesthetic judgment. As Myl'nikov, in his paper 'Francisk Skorina i Praga', points out (p. 25), this source may well have been the 1506 Czech Bible. A serious analysis of the translation of the crucial 
passages containing words for 'good' and/or 'beautiful' might produce some interesting insights; Konon's rather fragmentary, superficial approach will not.

T. N. Koprejeva's 'Francisk Skoryna i russkaja rukopisnaja tradicija XV v.' seeks to establish a direct link between Skaryna's translations and those of the Novgorod Judaizers (largely on the assumption that Skaryna could hardly have used the Hussite Bible as a prime source without considering analogous developments in Byelorussia and Muscovy). She quotes a number of passages from both, and the similarities are indeed striking. There is, however, insufficient information on the extent to which heretical ideas were spreading into the Grand Duchy of Lithuania during the second half of the fifteenth century, let alone on Skaryna's coniact with them before he went to Prague, for her interesting hypothesis to be fully acceptable.

One of the most interesting sections of the whole book is the appendix, consisting of a series of reproductions of engravings, initials, finials and borders, with accompanying descriptions.

In all there are 25 contributions, many of which contain interesting and useful information, although there is almost nothing that is significantly new. BPFS is well-produced but it does leave the reader with a somewhat 'fragmentary', 'compilatory' impression. We must look forward to the 'major marxist-leninist monograph' promised (threatened?) on p. 218, which is to follow the publication of a 'kompleks istočnikovedčeskich rabot'. Once again it must be stressed that Soviet scholars have the necessary resources to carry out this work; one can only wonder why they are so long in starting.

From works that have claim to serious scholarship we must now turn our attention to two that do not. The first is Skaryna $i$ naš čas by Viačesłaŭ Salkievič, published by 'Hołas Radzimy', Minsk, 1979. Primarily intended for the non-specialist Byelorussian reader in the emigration, it is relatively harmless, in that it contains so few facts about Skaryna's life and work as to be almost devoid of error. The author does have a tendency to digress at length in the manner of Gogol', the most noteworthy being a, to all intents and purposes, totally irrelevant discourse on Fichte's superego. He also enthuses to excess about the Malaja podorožnaja knižica by claiming that it contains medical information. The booklet does, however, contain some points of interest, not least of which is the quotation on p. 32 from Literaturnaja gazeta of 11 February 1976, in which mention is made of a 'śpiecyjalna prybyǔšy z Łondana pan' who did not spare his cash in purchasing individual printed sheets of Skaryna's Bible at an auction in Monte-Carlo. Let it be said quite clearly that the 'pan' was Fr Nadson and that the 'hrošy' were not his, but the sacrifice of Byelorussians living in the West, made in order that a valuable part of their cultural heritage might be preserved in the Skaryna Library in London.

A lengthy quotation on p. 20 illustrates the problem facing scholars in Soviet Byelorussia. Salkievič here translates into Byelorussian an extract from one of the Padua documents of 1512 which had pre- 
viously been published in Russian in Neman, 8, 1967. In its turn the Russian version had been translated (ostensibly) from the Latin originals published in Žurnal Ministerstva narodnogo prosveščenija, 4,1892 . It is of course not impossible that the impetus for the Russian translation was given by the publication of the Latin text with Byelorussian translation in issues 56, 61, 62/63 and $64 / 65$ of Znič, published in Rome in 1961 and 1962 as a result of the efforts of Fr Tatarynovič and Dr J. Sadoŭski. How ironic that Salkievič has to translate from Russian into Byelorussian a text that had already been translated direct from the original.

Of considerably greater importance, because specifically aimed at the foreign non-specialist, is Francisk Skorina by V. Cemerickij, G. Golenčenko and V. Hmatov (presumably Smatov), allegedly translated from Byelorussian into French by one Gilles Gâche and published in Paris by UNESCO in 1979. This little volume is published 'avec la collaboration de l'Association internationale pour l'étude et la diffusion des cultures slaves' (also known as MAIRSK) in the series 'Eminentes personnalités de la culture slave'. Despite what is said on the title page, it must remain seriously in doubt as to whether this book was in fact translated from Byelorussian. The authors' names clearly appear in Russian form, as does the name of the man about whom it was written. Since Skaryna is recognised as a Byelorussian, there is no need to render his name in a form transliterated from Russian. The text contains further evidence of the work's Russian origin: Erazm Ciołek (a Pole) has his name spelt Tëlok, Hussovianus of course appears as Gusovski, and the Czech Hašek is disguised as Gachek. Presumably for reasons other than the language of origin the Slovene Primus Truber appears as Trubeg and is moreover described as an 'imprimeur allemand'. By the same token Skaryna should be called a Czech printer. There are numerous other errors which one would like to think result from careless proofreading, e.g. Chronique de Byhobec, Henry VIII as King of England in 1483, Rey as a 14th-century Polish poet. On the one hand the reader is presented with a picture of Skaryna as an innovator, but on the other he is told (p. 36) that Skaryna relied on the 'tradition biélorusse' and the 'expérience de ses prédécesseurs'. This is altogether a miserable, error-laden production that does no credit whatsoever to the educational and cultural intentions of UNESCO; it should be withdrawn as soon as possible. The verso of the title-page gives the SBN of an English version; mercifully it has so far (July 1980) failed to surface.

It does not seem excessively fanciful to view these recent publications from the USSR as a direct riposte to the work of Braha, Nadson, Tatarynovič, Tumaš and other Byelorussians living in the West. Nemirovskij in the preface to his bibliography, and the unnamed author(s) of the first article in BPFS do not attempt to disguise their attitude. The chief criticism levelled at the work of émigré scholars is directed in particular at their allegedly nationalist distortions of historical fact, at their supposed assumption of the supremacy of the national Byelorussian viewpoint over questions of international 
contact and at their concomitant tendency to belittle related (in this instance, Russian) cultures. It certainly can and does happen that extraneous political considerations colour and even distort historical research; we must therefore bear in mind that there is a clearly discernible political motivation behind much Soviet Skaryna scholarship. Much space is spent in discussing his international contacts (real, hypothetical or merely hoped-for) with Muscovy to ensure that the much vaunted unity of the East Slavonic peoples is seen to be a reality throughout the centuries. Koprejeva's article in BPFS is a sood example of an approach whereby the need to locate Russian sources and influence becomes of overriding importance, although in this particular instance the result is not wholly dismissable. A truly disgraceful example of ideology assuming pride of place over considerations of fact or even credibility is the UNESCO publication mentioned above. It is clear that the intrinsic unity of the Byelorussian and Russion peoples is to be seen as an article of faith within Leninist dogma, but it is equally clear that good Soviet scholars produce excellent work and recognise the contribution of Byelorussians living in the West with no more than a perfunctory nod in the direction of ideology. Where the dictates of ideology have been suferseded, the results can be very confusing for the uninitiated. This is especially true in bibliographies (e.g. Nemirovskij's) and in compilative studies of books about Skaryna (e.g. pp. 50-78 of Salkievič's little book); the problem arises with the latest official policy regarding Skaryna's first name. The period of 'hieorhizacyja' (S. Braha's splendid term) appears to have come to an end in the USSR; bibliographies and surveys will inevitably continue to contain references to works about one Georgi/Hieorhij Skaryna. To the best of my knowledge not a single Soviet scholar has publicly recanted.

A great deal has been learnt about Skaryna's life and work over the past five decades. Byelorussian scholars in the West have played and continue to play a vitally important role in the discovery of more information relating to him; this ought to be regarded as an undisputed fact that goes far beyond considerations of past or present political loyalties. Giving credit to their achievements in no way lessens the recognition due to the equally genuine scholarship now emanating from the Soviet Union. There is undoubtedly much material still lying in archives awaiting discovery and publication. There are certainly still many questions unanswered. (For example, how many of the questions raised by Florovskij in his article 'Scoriniana' cited above are even broached in the latest Soviet publications, let alone answered?) Even without the discovery of new items, one issue cries out for proper investigation: the consideration of his translations within the whole context of Biblical study. For this, the comparison of isolated sentences in the manner of Konon or Koprejeva with other texts is clearly insufficient. What is needed is a thorough examination of Skaryna's texts alongside the Czech iranslation and the Vulgate, as well as the Septuagint and Old Church Slavonic versions. Only in this way can properly-based judgments be made on Skaryna's translations, whether printed or in manuscript. 
The chief items reviewed in this article are as follows:

Belorusskij prosvetitel' Francisk Skorina i načalo knigopečatanija v Belorussii i Litve, 'Nauka', Moscow, 1979. 279 pages. Illustrations.

Cemerickij, V., Golenčenko, G., Hmatov, V., Francisk Skorina. Traduit du biélorusse par Gilles Gâche. UNESCO, Paris, 1979. 78 pages. Illustrations.

Nernirovskij, Je. L. Načalo knigopečatanija $v$ Belorussii i Litve. Žizn' i dajstel'nost' Franciska Skoriny. Opisanije izdanij i ukazatel' literatury, 1517-1977. Gos. Bibl. SSSR im. V. I. Lenina, Moscow, 1978. 160 pages.

Salkievič, V. Skaryna i naš čas, 'Hołas Radzimy', Minslr, 1979. 78 pages.

\section{Authors of articles in Vol. IV, Nos 3-4}

J. DINGLEY, Senior Lecturer and Head of the Department of Russian, University of Reading.

R. J. PATRY-TAMUSHANSKI, Byelorussian broadcaster, Vatican Radio.

A. G. WARING, Senior Lecturer in Charge of the Department of Russian and Slavonic Studies, University of Sheffield.

P. WEXLER, Professor of Linguistics, University of Tel-Aviv. 